\title{
Confessions of a Flawed Liberal
}

\author{
Rebecca L. Brown \\ Allen Professor of Law \\ Vanderbilt Law School
}

A "ticket of admission" for the Constitutional Theory Discussion Group To continue the theme, not even a cheap seat: perhaps Standing Room Only...

My name is Rebecca and I am a flawed liberal. Indeed, I fear I am the person that this Discussion Group is about. I have such consistently liberal positions on nearly all things that a recent online candidate-matching test placed me at a $100 \%$ overlap with Al Sharpton. I voted for McGovern, for Dukakis, and only reluctantly for Clinton because he was too centrist for my taste. Ted Kennedy has never out-lefted me. I care first and foremost about individual rights and the protection of liberty from encroachment by overzealous and ungenerous majoritarian institutions. Yet -when it comes to the First Amendment, my sterling liberal credentials show a bit of tarnish. I have always hated Buckley v. Valeo, and not only the part invalidating contribution limits - I even deplore the basic claim that money is speech. I welcomed the recent McConnell decision as a hint of movement in the other direction, notwithstanding the inelegance of the opinion(s) and the pathetically ineffectual nature of the campaign finance reform law it upheld. My confession must also include an acknowledgment that I was the only 
person I knew who was deeply rankled by the Supreme Court's striking down of the law prohibiting virtual kiddy porn. My blood boils at the high degree of protection given to hate speech. And, ashamed though I am to admit it, I also own up to having felt very uncomfortable over the years with the ACLU's penchant for spending its limited resources defending the causes of Nazis and the Klan.

The question is, am I in need of a twelve-step program, or are the views I describe representative of some legitimate, and still liberal, perspective on constitutional law? Do I really believe less in freedom, constitutional democracy and individual rights than I thought I did, or else these terrible truths about me would not emerge every few Supreme Court Terms? Having gotten the confession out of the way, I wish to devote the remainder of this brief sketch to exploring how a liberal might, without hypocrisy, defend these seemingly inconsistent perspectives.

We all recognize that there are different visions of democracy that can be defended, even under the single American Constitution. Because that document and its history encompass so many strands of political thought, interwoven to create a complex democratic fabric, one can find threads of liberalism, pluralism, majoritarianism, republicanism, and any number of other -isms that might plausibly be said to characterize the country's basic 
commitments. This richness gives rise to lively debates in constitutional scholarship, and leads to radically different interpretative theories. ${ }^{1}$

Even liberalism itself is not a unified set of commitments or understandings about the entailments of democracy. The letter announcing this Discussion Group suggests a general correlation between "liberal” thought and hostility to government regulation, along with a corresponding “conservative” hostility to constitutional limits on government power. Characterized this way, the drift that we perceive might be thought to suggest a retreat of liberals from their commitments when they, in keeping with my opening confession, support certain regulation in the face of constitutional attack. This phenomenon was identified in connection with Jack Balkin’s intriguing suggestion over a decade ago of a latter-day legal realism insinuating itself into the consideration of modern free speech theory. $^{2}$

Another way to think about it is to consider what it is that liberals expect from their government. The perspective of the "flawed liberal" as contrasted with the true liberal can be roughly, but perhaps profitably, compared to two schools of liberalism, described as “comprehensive

\footnotetext{
${ }^{1}$ See Ronald Dworkin, Freedom's Law: The Moral Reading of the American Constitution 15-19 (1996) (attributing much interpretative disagreement to "a profound philosophical dispute about democracy's fundamental value or point").

${ }^{2}$ See J.M. Balkin, Some Realism About Pluralism: Legal Realist Approaches to the First Amendment, 1990 Duke L.J. 375 (1990).
} 
liberalism” and "political liberalism.”3 Painting with a broad brush, these two perspectives can be contrasted by the justifications that they offer for the adoption of a liberal state. The more traditional, comprehensive, liberal school sees the best state as one that provides political institutions and laws that maximize some other good, such as happiness, human flourishing, or equality and independence. The comprehensive liberal thus implements some philosophical viewpoint and adopts the liberal state as the best way to achieve that commitment. Theorists have, of course, disagreed on what that background commitment should be. The so-called "political liberal” justification for the liberal state departs from this traditional idea by seeking to justify the state irrespective of any substantive background commitment. Rawls, for example, offers a more "freestanding" view of society that is not dependent on a background substantive moral theory. ${ }^{4}$ It claims to avoid the age-old philosophical battles occasioned by reasonable pluralism by constructing a state that does not self-consciously adopt or promote any philosophical or moral doctrine.

These different teleological commitments between political liberalism, on the one hand, and comprehensive liberalism on the other, have

\footnotetext{
${ }^{3}$ See generally Stephen A. Gardbaum, Liberalism, Autonomy, and Moral Conflict, 48 STAN. L. REV. 385 (1996).

${ }^{4}$ See Robert B. Talisse, On Rawls 55-59 (2001).
} 
given rise, in less abstract contexts, to some generalizations about appropriate limits on state behavior under the two types of regime. In particular, some have suggested that these perspectives give rise to different views of a state's obligation to remain neutral with regard to competing moral ideals held by its citizens. ${ }^{5}$ Political liberalism is committed to ensuring that a state does not privilege any of the competing understandings of the good life, and holds as a core value state neutrality with respect to all such understandings, out of respect for pluralism. ${ }^{6}$ The justification for this conviction lies in the recognition that no single principle or ideal can command universal belief among people, and that, therefore, justice requires that none of them be privileged by the basic political institutions of society. ${ }^{7}$ This commitment ensures that no controversial ideal of the good will be called upon to justify the fundamental political principles under which all must live. Rather, the state will adhere only to the appropriately "political" commitments, such as the political conception of persons as free and equal, while remaining impartial as to the more comprehensive moral doctrines held by private individuals. Neutrality is the required posture for government, with respect both to its ends (not selecting among contested

\footnotetext{
${ }^{5}$ See Stephen Gardbaum, Liberalism, Autonomy, and Moral Conflict, 48 Stan. L. Rev. 403 (1995-1996).

${ }^{6}$ See John RAWLS, POLITICAL LiBERALISM xix-xxiv (1993)(describing the need for state impartiality in a society of reasonable pluralism).

${ }^{7}$ Charles Larmore, PatTerns of Moral Complexity 43-44 (Cambridge, 1987).
} 
values) and its means (not acting in a way that gives preference to any perspective or group).

Applying the general principles of comprehensive liberalism to government behavior requires some choice among the background philosophies that the comprehensive liberal embraces. The central objective of this strand of liberalism is to enable the state to facilitate the moral lives of its citizens, and thus to contribute to their fulfillment as human beings. Many believe that the particular conception of the good to which a general comprehensive liberalism is committed must be the promotion of individual self-definition or autonomy. According to this belief, the state's proper role is not merely to leave citizens as it finds them to work out their lives for themselves. Rather, the state may have an affirmative obligation to promote human flourishing, inevitably involving itself in endorsing some substantive values consistent with its underlying commitments.

A state meets its obligation to promote flourishing by allowing people to make real choices about the directions that their lives will take, uncoerced by design or circumstance. It happens that, in privileging this ideal of autonomy, the state will often find it necessary or desirable to remain neutral. This is not because neutrality is itself an objective of the state, but because in many cases state neutrality will be the best way to promote the 
value of autonomy by increasing freedom of choice for citizens. For example, if a state stays out of all religious discourse, citizens will generally have an unconstrained choice about their own religious preferences. This approach would satisfy political and comprehensive liberals alike.

For comprehensive liberals, however, it may sometimes become necessary for the state to promote certain ways of life rather than others, in the interest of autonomy as the greatest moral good. For example, if one particularly intolerant religion became so dominant in the private sector that people of other religions were subjected to rampant discrimination in employment, housing, and private social institutions, the comprehensive liberal might well determine that the state had an obligation to use government vehicles to open the doors of opportunity for the excluded groups. It is apparent, then, that political and comprehensive liberalism are not merely two means to the same end. The former sees state neutrality as a defining and constitutive precept, while the latter employs it as needed to further its own constitutive ideals, autonomy being a commonly identified such ideal.

Both the adoption of autonomy as the goal of the state and the commitment to state neutrality reflect the origins of liberalism itself. By rejecting the once-dominant world view that assigned individuals, by birth, 
to roles in life that placed them permanently in some immutable position in a hierarchical political society, liberalism replaced a belief in natural hierarchy with a belief in natural equality. The liberal innovation saw political society as needing a justification consistent with the premise of equality. Both of these variants on liberalism supply such a justification.

The point of divide between the two comes when circumstances are such that merely remaining neutral will not permit the state to ensure the attainment of individual flourishing for some citizens. When faced with this dilemma, the political liberal must sacrifice flourishing for the sake of neutrality; the comprehensive liberal will, if necessary, sacrifice neutrality for the sake of individual fulfillment. State coercion of individual choice would offend both liberal schools by undermining both autonomy and neutrality. But the comprehensive liberal goes further than simply condemning state coercion. The comprehensive liberal claims that just as the state has the unique ability and duty to protect life, liberty, and property against dangers posed by other individuals, so too it may have an obligation to counter constraints on autonomy generated by private elements of society. This is not a very different conclusion from the one, reached via a different route, "that public expansion or contraction of rights is really an issue of 
relations of power between private individuals." ${ }^{\text {" This }}$ point addressed the aspect of free speech having to do with access, but seems to me to apply across First Amendment law and, perhaps, beyond. Whenever economic, educational, or informational barriers impede the exercise of meaningful life choices, it could well be said that "[a] libertarian conception of free speech [or rights in general?] has served us well in the past, but like all conceptions, it can and eventually must run out of steam and degenerate into a sterile conception that will hinder progressive reform rather than aid it.” 9

Although probably not true of all theorists who profess comprehensive liberalism, I understand this approach to fit very well with constitutional theory that places a high value on equality. Indeed, if one posits a thick and robust notion of equality as a starting point for political justice, it may well follow that governments have some obligation, or at least could be permitted, to address gross disparities in ways that a libertarian view would not support, nor would a liberal view committed to state neutrality.

Turning to some of the examples with which I began, the idiosyncratic instincts may in fact fall together in some sort of intelligible pattern. A

\footnotetext{
${ }^{8}$ J.M. Balkin, Some Realism About Pluralism: Legal Realist Approaches to the First Amendment, 1990 Duke L.J. 375, 404 (1990).

${ }^{9}$ Id. at 412.
} 
defense of limits on campaign finance reform could be understood in a manner that is consistent with comprehensive liberal theory. The argument would be that, just as it would be unthinkable for a state affirmatively to allow any type of endowment to entitle one person to a louder voice than others have in the political process, it is likewise not defensible to allow wealth to accomplish the same thing passively through the private ordering of the channels of mass communication. That is, the state would be using its regulatory authority to equalize an unequal access to the means of persuasion. Surprisingly, Ronald Dworkin raised a similar argument in his attack on Buckley v. Valeo, when he suggested that the self-government contemplated by our democracy includes the rights of those who wish to command the attention of others as well as those who wish to hear what others have to say. ${ }^{10}$ Thus, he argued, the Supreme Court had incorrectly viewed the campaign expenditure limits as interferences with the selfgovernment protected by the First Amendment.

The prohibition of hate speech seems the easiest of all regulations to justify under a comprehensive liberal approach to the First Amendment. The idea is that, if the state's obligation is to promote the flourishing of all its citizens, a primary obligation is to ensure that each citizen is able to

${ }^{10}$ Ronald Dworkin, The Curse of American Politics, The New York Review, Oct. 17, 1996, at 23. 
participate on equal terms in the informal cultural life of the community, to

be a full-fledged participant in the moral and social environment, and to live a life undiminished by the condemnations of others. Thus, while the neutralstate type of liberalism believes that the state's obligation to its citizens is compromised when government prohibits speech on the ground that it is offensive or degrading, ${ }^{11}$ the comprehensive view should suggest just the opposite. That is, speech is protected for the purpose of promoting selfgovernment, but speech that tries to exclude some from the polity, by claiming that they are of inferior status in some essential way, offends the premise of equality and thus should not be part of the realm of protected expression. An application of Dworkin's principle of equal concern and respect ought, in my view, if not Dworkin's, ${ }^{12}$ to lead to the same conclusion. Other countries such as Germany, for example, have explicitly

\footnotetext{
${ }^{11}$ Dworkin at 21.

${ }^{12}$ Dworkin most assuredly does not support this application of his principle of equal concern and respect. He believes there is a strong egalitarian claim to have the chance to be heard, but not a comparable equality-based interest in not being degraded or dehumanized by the speech of others. Ronald Dworkin, Freedom’s Law 236-237 (1996). With tremendous respect, I do think his own principles could plausibly be applied differently. For example, he states that self-government is not guaranteed "unless all the members of the community in question are moral members. German Jews were not moral members of the political community that tried to exterminate them, though they had votes in the elections that led to Hitler's Chancellorship....” Id. at 23. It is not a large step to say that a government that feels the need to restrict some forms of hate speech for the purpose of protecting the moral status of citizens, although not required constitutionally to do so, may do so without violating the First Amendment.
} 
determined that the principle of equality should override the freedom to degrade, diminish and exclude from full moral status via speech.

In my children's lower school, there are only two rules regulating speech on the playground. One is no teasing, and the other is, "You can't say you can't play.” These are two rules that I suggest illustrate the application of the comprehensive liberal commitment to ensuring equal moral status. The teasing goes to the degradation that is analogous to hate speech. The "can’t play" rule goes to the heart of what it means to be a participant in the community. In this respect, the equality principle gives rise to certain entitlements to liberty—-the liberties necessary to enjoy full membership in the relevant polity. It should not offend the liberal credo to stifle the one expression so antithetical to self-government—exclusion.

In the end, it seems to me to be unhelpful to focus too much on what liberals would or ought to think about regulation and rights. The real question that the "ideological shift" points to is what we expect from our government, in an age of increasing heterogeneity of both circumstance and values among people. Especially in light of increasing polarization of wealth and poverty, the deep liberal commitments that might naturally lead us to prefer state neutrality in times of greater background fairness may now legitimately lead us to question that neutrality as insufficient to permit our 
nation to meet the new challenges we face. A more robust, affirmative employment of equality principles may be called for to help us get past the idea that if the state simply does not legislate harm, the private sphere will take care of itself. In allowing our commitments to evolve with societal change in this way, we have not lost our claim to liberalism. We just need a few support sessions with Flawed Liberals Anonymous. 